\title{
IDAHO GROUND-WATER QUALITY
}

\author{
By D.J. Parliman
}

U.S. Geological Survey Open-File Report 87-0722 


\section{DEPARTMENT OF THE INTERIOR}

DONALD PAUL HODEL, Secretary

\section{U.S. GEOLOGICAL SURVEY}

Dallas L. Peck, Director

For additional information:

Chief Hydrologist

U.S. Geological Survey

407 National Center

Reston, VA 22092
For sale by:

Open-File Services Section

U.S. Geological Survey, MS 306

Box 25425, Federal Center

Denver, CO 80225

(303) 234-5888

Use of trade names in this report is for descriptive purposes only and does not constitute endorsement by the U.S. Geological Survey 


\section{FOREWORD}

This report contains summary information on ground-water quality in one of the $\mathbf{5 0}$ States, Puerto Rico, the Virgin Islands, or the Trust Territories of the Pacific Islands, Saipan, Guam, and American Samoa. The material is extracted from the manuscript of the 1986 National Water Summary, and with the exception of the illustrations, which will be reproduced in multi-color in the 1986 National Water Summary, the format and content of this report is identical to the State ground-water-quality descriptions to be published in the 1986 National Water Summary. Release of this information before formal publication in the 1986 National Water Summary permits the earliest access by the public. 


\section{Contents}

Ground-Water Quality $\ldots \ldots \ldots \ldots \ldots \ldots \ldots \ldots \ldots \ldots \ldots \ldots \ldots \ldots$

Water-Quality in Principal Aquifers $\ldots \ldots \ldots \ldots \ldots \ldots \ldots \ldots \ldots \ldots \ldots \ldots \ldots \ldots \ldots \ldots$

Background Water Quality $\ldots \ldots \ldots \ldots \ldots \ldots \ldots \ldots \ldots \ldots \ldots \ldots \ldots \ldots$

Nonthermal Water $\ldots \ldots \ldots \ldots \ldots \ldots \ldots \ldots \ldots \ldots \ldots \ldots$

Thermal Water $\ldots \ldots \ldots \ldots \ldots \ldots \ldots \ldots \ldots \ldots \ldots \ldots \ldots \ldots$

Effects of Land Use on Water Quality $\ldots \ldots \ldots \ldots \ldots \ldots \ldots \ldots \ldots$

Potential for Water-Quality Changes ................... 4

Ground-Water-Quality Management .................... 4

Selected References $\ldots \ldots \ldots \ldots \ldots \ldots \ldots \ldots \ldots \ldots \ldots \ldots \ldots \ldots \ldots \ldots$

Illustrations

Figure 1.--Selected geographic feature and 1985 population distribution in Idaho.

Figure 2.--Principal aquifers and related water-quality data in Idaho.

Figure 3.--Selected waste sites and ground-water quality information in Idaho. 


\section{IDAHO Ground-Water Quality}

Idaho ranks as one of the top five States in the United States for volume of ground water used. Total ground-water pumpage was about 6.3 billion gallons per day in 1980 (U.S. Geological Survey, 1985, p. 193). Between 1980 and 1985, an increasing demand for ground water accompanied a statewide population growth of 6.4 percent (Allan Porter, Idaho Department of Commerce, oral commun., 1986). (See distribution of population in fig. 1.)

Although quantities of ground water for public and rural use are only about 3 percent of total ground-water pumpage, ground water is currently the principal source of more than 90 percent of public water supplies and 79 percent of rural-domestic and livestock supplies; these are large percentages compared to those of most other States. Many drinking-water supplies are pumped from relatively shallow aquifers (fig. 2), where the potential is large for degradation of ground water by land- and water-use activities.

Idaho's economy is dominated by agriculture and agriculture-related businesses such as food and meat processing, feedlots, dairies, aquaculture, and farm chemical, feed, fuel, or equipment supply. The most agriculturally developed and intensely populated areas in the State are valley lowlands and plains. These areas generally receive only 8 to 12 inches of precipitation per year. From about May to October, billions of gallons of both surface and ground water are applied to crops and pastureland each day to supplement infrequent rainfall.

Many potential sources of ground-water degradation are associated with agriculture or agriculture-related activities. Irrigation practices and land application of billions of gallons of wastewater from agriculture-related activities are major sources of recharge to many aquifers in the State and are direct or indirect sources of contaminants such as nitrate, iron, organic compounds, and bacteria. More importantly, recharge from land-use activities may transport contaminants from land surface to ground-water systems (fig. 3).

However, the most significant known and potential sources of groundwater contaminants are related to urban land use. The Idaho Department of Health and Welfare identified 17 land- and water-use activities as potential sources of ground-water contamination (Burr, 1986). Of these 17 activities, contamination is most frequently related to movement, storage, or transfer of petroleum or hazardous materials and land disposal of solid and liquid wastes.

Six hazardous-waste sites, including one commercial disposal facility near Grand View (Owyhee County), currently are regulated under the Resource Conservation and Recovery Act (RCRA) of 1976 (fig. 3A). Four additional sites have been included on the National Priorities List (NPL) of hazardous-waste sites (U.S. Environmental Protection Agency, 1986c) for assessment and cleanup action under the Comprehensive Environmental Response, Compensation, and Liability Act (CERCLA) of 1980. Known or potential ground-water contaminants at RCRA and CERCLA sites include solvents, wood preservatives, polychlorinated biphenyls (PCB's), petroleum products, and ore-processing wastes (lead and cadmium). An additional 39 sites, which currently are not subject to RCRA or CERCLA regulation, have received a preliminary site assessment, have potential or known groundwater contamination, or are awaiting further evaluation before monitoring or cleanup activities may be considered. In addition, the U.S. Department of Defense (DOD) has identified four sites at one facility where contamination has warranted response action.

Ground water in Idaho can be divided into two major typesnonthermal (temperature less than $\left.26^{\circ} \mathrm{Celsius}\right)$ and thermal $\left(26^{\circ} \mathrm{Celsius}\right.$ or greater) (Wood and Low, 1987). Chemical characteristics and suitability for use of ground water differ throughout the State. In general, nonthermal ground water has good to excellent chemical quality, is suitable for most uses, and meets national drinking-water standards (U.S. Environmental Protection Agency, 1986a,b). In localized areas, use of very mineralized nonthermal water may be restricted for health, economic, or esthetic reasons. The quality of thermal ground water also is generally good for many uses, but concentrations of a few constituents in thermal water may exceed drinking-water standards or may be harmful to livestock or selected crops in some areas. Use of thermal water for crop and pasture irrigation can result in an accumulation of salts in soils.
Ground-water-quality data are sparse in most parts of the State, and few data are available to describe temporal variations of water quality in most aquifers. Although numerous local, State, and Federal agencies, as well as private organizations, collect and analyze hundreds of ground-water samples each year (Parliman and Brower, 1985), methods of data storage are different. Publication or distribution of data may be limited. Also, sampling methods and onsite sample preservation techniques are not standardized among the many agencies, and comparability of historical and current data may be questionable both within and among agencies. Analyses of synthetic organic, pesticide, and petroleum compounds are sparse, but a national survey by the U.S. Environmental Protection Agency (EPA) in 1981 indicated low-level contamination by synthetic organic compounds in 8 of 14 Idaho public water supplies (Westrick and others, 1984).

\section{WATER QUALITY IN PRINCIPAL AQUIFERS}

Seventy aquifers have been identified in Idaho, but some are limited in extent and yield insignificant amounts of water (U.S. Geological Survey, 1985 , p. 193). Three principal aquifers have been defined and are characterized by their distinctive geology (fig. $2 A$ )-valley-fill aquifers, basalt aquifers, and sedimentary and volcanic aquifers.

Valley-fill aquifers consist of unconsolidated sediments in intermontane valleys; water-yielding zones are most commonly unconfined. Recharge to valley-fill aquifers is primarily from infiltration of precipitation and leakage from surface-water sources. The chemical character of water in these aquifers is extremely varied, because of the diverse composition of anuifer materials. Principal valley-fill aquifers are located in northern and southeastern Idaho, and in the central Idaho mountains.

Basalt aquifers are characterized by numerous basalt flows and thin, interbedded sediments or pyroclastics. Water-yielding zones may be confined or unconfined. Major sources of recharge are infiltration of irrigation water; seepage from canals, streams, and rivers; and underflow from tributary basins. The principal basalt aquifer, which is the largest yielding aquifer in the State, underlies the eastern Snake River Plain (Sun, 1986).

Sedimentary and volcanic aquifers consist of unconsolidated sediment with basalt and felsic rock and interbedded shale and sandstone. Water-yielding zones may be confined or unconfined. Major sources of recharge are infiltration of irrigation water and seepage from canals and rivers. Principal aquifers of this group chiefly underlie the western Snake River Plain.

Each of these principal aquifers contains both nonthermal and thermal ground water. Generalized locations of inventoried thermal water resources are included in figure $2 B$. Nonthermal water may be from confined or unconfined water-yielding zones, commonly less than 400 feet below land surface. Nonthermal water is used mainly for domestic, irrigation, and industrial purposes. Thermal water is commonly from confined zones more than 400 feet below land surface and is used most commonly for irrigation, aquaculture, space heating, health spas, or recreation. Zones of mixed thermal and nonthermal water are common and can result from upward leakage of thermal water in open well boreholes or through faulted and fractured rock.

Significant thermal-water resources are associated with valley-fill aquifers in southeastern Idaho, basalt aquifers near Twin Falls and Burley, and all the sedimentary and volcanic aquifers in southwestern Idaho. Statewide, about 21,800 acres are designated as known geothermal resource areas and nearly 15 million acres (about 30 percent of the State) are classified as potentially valuable for geothermal exploration (Young and Mitchell, 1973). Although 
the potential volume of thermal water is relatively small compared with that of nonthermal water, water users in many parts of Idaho rely on thermal-water supplies for most nondrinking water needs, particularly for irrigation.

\section{BACKGROUND WATER QUALITY}

A graphic summary of selected water-quality variables compiled from the U.S. Geological Survey's National Water Data Storage and Retrieval System (WArsTORE) is presented in figure $2 C$. The summary is based on dissolved-solids, hardness (as calcium carbonate), nitrate plus nitrite (as nitrogen), fluoride, and $\mathrm{pH}$ analyses of water samples collected from 1970 to 1986 from the principal aquifers in Idaho. Data for both nonthermal and thermal water are shown for each principal aquifer. Percentiles of these variables are compared to national standards that specify the maximum concentration or level of a contaminant in drinking-water supply as established by U.S. Environmental Protection Agency (1986a,b). The primary maximum contaminant level standards are health related and are legally enforceable. The secondary maximum contaminant level standards apply to esthetic qualities and are recommended guidelines. The primary drinking-water standards include a maximum concentration of $10 \mathrm{mg} / \mathrm{L}$ (milligrams per liter) nitrate (as nitrogen) and $4 \mathrm{mg} / \mathrm{L}$ fluoride; the secondary drinking-water standards include maximum concentrations of $500 \mathrm{mg} / \mathrm{L}$ dissolved solids, 6.5-8.5 units of $\mathrm{pH}$, and $2 \mathrm{mg} / \mathrm{L}$ fluoride. In addition, a summary of the maximum values for selected water-quality properties or constituents in the principal aquifers is given as follows:

Maximum values for selected water-quality properties or constituents, 1970-86

(Data from U.S. Geologlcal Survey water-quality files)

(Properties or dissolved constituents reported in degrees Celsius, ${ }^{\circ} \mathrm{C}$; milligrams per liter, $\mathrm{mg} / \mathrm{L}$; or micrograms per liter, $\mu \mathrm{g} / \mathrm{L}$ )

\begin{tabular}{|c|c|c|c|c|c|c|}
\hline \multirow[b]{3}{*}{ PROPERTY OR CONSTITUENTS } & \multicolumn{6}{|c|}{ PAINCIPAL AQUIFERS } \\
\hline & \multicolumn{2}{|c|}{ Valley-fill } & \multicolumn{2}{|c|}{ Basait } & \multicolumn{2}{|c|}{ sedimentary and volcanic } \\
\hline & Nontharmal & Thermal & Nonthermal & Tharmal & Nonthermal & Tharmal \\
\hline Temperature $\left({ }^{\circ} \mathrm{Cl}\right.$ & 25.5 & 95.0 & 25.5 & 76.0 & 25.5 & 84.5 \\
\hline Alkalinity, total $\left(\mathrm{mg} / \mathrm{L}\right.$ as $\left.\mathrm{CaCO}_{3}\right)$ & 810 & 430 & 520 & 630 & 1,580 & 830 \\
\hline \multicolumn{7}{|l|}{ Dissolved solids (calculated sum } \\
\hline of constituents, $\mathrm{mg} / \mathrm{L}$ ) & 6,600 & 3,600 & 1,500 & 1,000 & 2,400 & 1,000 \\
\hline Hardness ( $\mathrm{mg} / \mathrm{L}$ as $\mathrm{CaCO}_{3}$ ) & 1,600 & 330 & 610 & 280 & 1,700 & 250 \\
\hline pH & 9.8 & 9.2 & 11.6 & 9.3 & 9.6 & 10.2 \\
\hline Chloride (mg/L as Cl) & 3,900 & 2,100 & 830 & 83 & 430 & 88 \\
\hline Fluoride $(\mathrm{mg} / \mathrm{L}$ as $\mathrm{F})$ & 11 & 14 & 7 & 13 & 17 & 30 \\
\hline Nitrate plus nitrite (mg/L as $\mathrm{N}$ ) & 25 & 1.5 & 22 & 2 & 29 & 3.8 \\
\hline Sodium (mg/L as $\mathrm{Na}$ ) & 2,000 & 1,300 & 470 & 330 & 570 & 330 \\
\hline Sulfate $\left(\mathrm{mg} / \mathrm{L}\right.$ as $\left.\mathrm{SO}_{4}\right)$ & 1,100 & 270 & 420 & 170 & 1,400 & 240 \\
\hline Arsenic $(\mu \mathrm{g} / \mathrm{L}$ as As) & 170 & 510 & 23 & 18 & 68 & 80 \\
\hline Boron $(\mu \mathrm{g} / \mathrm{L}$ as $\mathrm{B})$ & 2,400 & 7,800 & 330 & 2,200 & 1,700 & 2,100 \\
\hline Iron $(\mu \mathrm{g} / \mathrm{L}$ as $\mathrm{Fe})$ & 18,000 & 40 & 7,000 & 50 & 6,100 & 410 \\
\hline Manganese $(\mu \mathrm{g} / \mathrm{L}$ as $\mathrm{Mn})$ & 3,200 & 520 & 5,100 & 10 & 7,700 & 110 \\
\hline
\end{tabular}

\section{Nonthermal Water}

Chemical quality of nonthermal water generally is suitable for most uses and does not exceed the national drinking-water standards. Very mineralized ground water occurs naturally in localized areas statewide, particularly in sediments where nonthermal and thermal waters mix or where water is confined in organic-rich sediments. Very mineralized water may restrict water use because of health, economic, and esthetic reasons.

Nonthermal water in all aquifers contains predominantly calcium, magnesium, and bicarbonate ions or calcium, sodium, and bicarbonate ions. Where nonthermal water is very mineralized, $\mathrm{pH}$ or concentrations of dissolved solids, sulfate, chloride, fluoride, arsenic, iron, manganese, or selenium may be unusually large and may exceed primary and secondary drinking-water standards. Extremely hard water or anomalously large concentrations of alkalinity, sodium, or boron can make the water unsuitable for some domestic, industrial, or agricultural uses. Shallow, nonthermal water can become more mineralized by upward leakage of thermal water or by downward percolation of thermal water used for irrigation.

In most instances, very mineralized water is the result of natural geologic and hydrologic conditions in aquifers. Maximum concentrations of constituents generally are associated with nonthermal water in fine-grained lake or stream deposits in the valleyfill or sedimentary and volcanic aquifers. Anomalously large or restrictive concentrations of some trace metals, most commonly iron and mianganese, may be related to land- and water-use activities. For example, maximum concentrations of iron and manganese in nonthermal water from basalt aquifers resulted from land application of food-processing wastewater (Parliman, 1986a).

Chemical characteristics of nonthermal water in principal aquifer groups (numbers $1 A, 2 A$, and $3 A$ in fig. $2 C$ ) were relatively uniform. At least 75 percent of dissolved-solids concentrations did not exceed the secondary drinking-water standard of $500 \mathrm{mg} / \mathrm{L}$. Most nonthermal water was moderately hard to very hard; therefore, many consumers prefer to soften their water. More than 90 percent of the nitrate (as nitrogen) concentrations did not exceed the primary drinking-water standard of $10 \mathrm{mg} / \mathrm{L}$, but many concentrations in nonthermal water were larger than the estimated natural background level of about $1 \mathrm{mg} / \mathrm{L}$ (few nonthermal water-quality data before intensive land use are available). More than 90 percent of the $\mathrm{pH}$ values for nonthermal water were within the established drinking-water range of 6.5 to 8.5. More than 75 percent of the fluoride concentrations in nonthermal water were smaller than $\mathbf{0 . 8}$ $\mathrm{mg} / \mathrm{L}$. Optimum State recommended limits for fluoride in public water supplies in Idaho, based on annual average maximum daily air temperatures, range from about 1.8 to $2.4 \mathrm{mg} / \mathrm{L}$ (Parliman 1983, 1986b).

Although nitrate plus nitrite (as nitrogen) concentrations commonly are smaller than $1 \mathrm{mg} / \mathrm{L}$ statewide, the median concentrations are largest in nonthermal water. Annual or seasonal increases in nitrate plus nitrite (as nitrogen) concentrations or concentrations that exceed about $2 \mathrm{mg} / \mathrm{L}$ probably indicate degradation of groundwater quality from land- and water-use activities. The largest median nitrate plus nitrite (as nitrogen) concentration was in nonthermal water from the basalt aquifers. Most of the basalt aquifer data were 
from the eastern Snake River Plain-an area of intensive and varied agricultural, industrial, and urban development.

Water-yielding zones that produce methane gas occur in areas with nonthermal and thermal water, principally in the sedimentary and volcanic aquifers of the western Snake River Plain and northern Owyhee County. Methane-producing wells are common throughout these areas, but areal and vertical distribution of ground-water related methane resources are generally unknown.

\section{Thermal Water}

Thermal water is suitable for many uses and contains predominantly sodium, bicarbonate, and sulfate ions or, rarely, sodium and chloride ions. In some areas, $\mathrm{pH}$ or concentrations of dissolved solids, sodium, fluoride, arsenic, or boron exceed primary and secondary drinking-water standards, and can be harmful to livestock or some crops, or can result in an accumulation of salts in soils.

In contrast to nonthermal ground water, chemical characteristics of thermal water in principal aquifers (numbers $1 B$, $2 B$, and $3 B$ in fig. $2 C$ ) were diverse and often distinctive. Median values for dissolved solids, $\mathrm{pH}$, and fluoride were larger in thermal water than in nonthermal water, but median values for hardness and nitrate (as nitrogen) were smaller in thermal water than in nonthermal water. The largest median dissolved-solids concentration was from thermal water in the valley-fill aquifers in southeastern Idaho. Hardness of thermal water in valley-fill and basalt aquifers ranged widely from soft to very hard; however, nearly 90 percent of the water in sedimentary and volcanic aquifers was soft. Nitrate plus nitrite (as nitrogen) concentrations were consistently small in thermal water. At least 50 percent of the nitrate plus nitrite (as nitrogen) concentrations from thermal waters in all aquifers were less than the detection limit of $0.1 \mathrm{mg} / \mathrm{L}$, an indication that thermal water is not being degraded by land-use activities. The largest median $\mathrm{pH}$ and fluoride concentration were from thermal water in sedimentary and volcanic aquifers.

\section{EFfects of LAND USE ON WATER QUaLITY}

Most known and potential sources of ground-water contamination have been ranked on the basis of risk of harm and drinking-water standards (Idaho Department of Health and Welfare, $1985 \mathrm{c})$. The ranking is as follows, from greatest to least risk: petroleum handling and storage; feedlots and dairies; landfills and hazardous-waste sites; land application of wastewater; hazardousmaterial handling; pesticide handling and use; land spreading of sludge and solid or liquid septic-tank pumpage; surface runoff; pits, ponds, and lagoons; radioactive substances; fertilizer application; septic-tank systems; mining, including oil and gas drilling; wells (injection, geothermal, domestic); and silviculture activities. Ground-water contamination from these land- or water-use activities can be caused by large concentrations of one or more of the following constituents: dissolved solids; sulfate; chloride; fluoride; sodium; nitrogen compounds; phosphate compounds; trace metals including iron, manganese, or zinc; radiochemicals; detergents; pesticides; toxic metals such as cadmium or chromium; petroleum products; or hazardous organic chemicals including solvents, wood preservatives, and PCB's (Yee and Souza, 1984; S.L. Lund, Idaho Department of Health and Welfare, oral commun., 1986). Biological contaminants include bacteria, viruses, and possibly giardia lamblia.

In 1985, the Idaho Department of Health and Welfare (1986b) established a Contamination Log to record occurrences of potential or known ground-water contamination. The log is a compilation of information about spills in nine categories of contaminants, including pesticides and releases of chemicals from mining, landfills, and other activities. As of January 1, 1986, 252 incidents of potential or known contamination were recorded; however, records before 1980 are sparse. Although documentation and reporting of incidents have not been consistent statewide, incidents reported since 1980 generally are located in urban areas and frequently are associated with movement, storage, or transfer of petroleum or hazardous materials and land disposal of solid and liquid wastes.

Waste-disposal sites and known or potential areas of groundwater contamination are shown in figure 3 . Figure $3 A$ shows locations of the following: (1) 4 CERCLA (Superfund) hazardous-waste sites; (2) 6 RCRA hazardous-waste sites; and (3) 51 other sites which include 12 industrial or municipal/industrial waste-disposal sites and 39 sites, not currently regulated under RCRA Or CERCLA, that have potential or known hazardous-materials contamination. Contaminants commonly associated with waste- disposal sites are industrial solvents, wood preservatives (creosote, pentachlorophenol), PCB's, petroleum products, and ore-smelting wastes (lead and cadmium).

As of September 1985, 12 hazardous-waste sites at 2 facilities in Idaho had been identified by the U.S. Department of Defense as part of their Installation Restoration Program (IRP) as having potential for contamination (U.S. Department of Defense, 1986). The IRP, established in 1976, parallels the EPA Superfund program under CERCLA of 1980 . The EPA presently ranks these sites under a hazard ranking system and may include them in the NPL. Four sites at one facility (fig. $3 A$ ) were considered to present a hazard significant enough to warrant response action in accordance with CERCLA. Ground water at 1 of the 12 sites at the U.S. Air Force Base near Mountain Home is being monitored and evaluated as part of the IRP.

Figure $3 B$ shows major areas where the potential exists for degradation of ground-water quality because of nonsewered urban and industrial development, agricultural irrigation, drain-well use, Idaho National Engineering Laboratory activities, and major mining and related processing activities. Most contamination occurs in discrete locations; therefore, patterns in figure $3 B$ represent those areas of the State with the greatest potential for or frequency of contamination from a particular source. Generalized areas where known and potential ground-water contamination are most frequently reported in the Department of Health and Welfare's Contamination Log are also shown in this figure. Naturally impaired water quality occurs locally in every part of the State, but in most instances, data on very mineralized water are most complete in areas with thermal, mixed thermal, and nonthermal water-yielding zones.

Contaminants associated with nonsewered urban and industrial development near Coeur d'Alene and Boise include the following: dissolved solids, nitrate, bacteria, iron, manganese, toxic organic wastes from household chemicals such as trichloroethylene (TCE), petroleum products (pesticides, solvents, wood-treatment products), and food-processing wastes (Jones and Lustig, 1977; Idaho Department of Health and Welfare, 1985b). Several hazardouswaste sites, currently regulated or being evaluated for RCRA action, are located in these areas (fig. $3 A$ ). Valley-fill aquifers in northern Idaho are particularly susceptible to contamination from surface sources. The largest valley-fill aquifer in northern Idaho was designated as a sole source aquifer (sole or principal source of drinking water) in 1976 under the Safe Drinking Water Act (Jones and Lustig, 1977).

The State's only commercial hazardous waste-disposal site, in northern Owyhee County, overlies numerous nonthermal and thermal water-yielding zones of the sedimentary and volcanic aquifer group. Some organic contaminants have been detected in ground water at the site (S.L. Lund, Idaho Department of Health and Welfare, oral commun., 1986). Concern exists not only for further contamination and migration of contaminants, but also for spillage of hazardous materials being transported to the site on highways.

Contaminants associated with irrigation and street or highway drain wells include suspended sediments, dissolved solids, bacteria, sodium, chloride, nitrate, phosphate, organic compounds (including 
pesticides), and lead. Of these constituents, suspended sediments, bacteria, and lead may pose a risk to some domestic ground-water supplies (Idaho Department of Health and Welfare, 1985a). Nearly 1,900 drain wells have been inventoried in Idaho, and of these, 1,590 are in use, primarily in the eastern Snake River Plain (W.G. Graham, Idaho Department of Water Resources, oral commun., 1986). All injection wells, authorized for construction and use within the area overlying the eastern Snake River Plain, are EPA subclass V (nonhazardous or nonradioactive fluid injection). Current injection wells probably present minimal hazards to regional groundwater quality. However, because the eastern Snake River Plain basalt aquifer is being considered for sole source aquifer designation, this widespread disposal practice is being closely monitored by the Idaho Department of Water Resources.

The Idaho National Engineering Laboratory encompasses about 980 square miles and overlies part of the eastern Snake River Plain basalt aquifer. The facility, which was established in 1949 to build and test nuclear reactors, currently stores chemical radioactive wastes from this and other sites across the United States. Contaminants associated with these activities include dissolved solids, sodium, sulfate, chloride, nitrate, chromium, solvents, and radionuclides including tritium, strontium- 90 , iodine-129, cobalt- 60 , cesium-137, and plutonium (Robertson and others, 1974; Leenheer and Bagby, 1982; Lewis and Jensen, 1984; Yee and Souza, 1984). Concern exists for both migration of contaminants from the site and spillage of materials being transported to the facility.

Known and potential contaminants from mining and related processing activities in northern and southeastern Idaho include phosphate compounds, fluoride, radiochemicals, and metallic trace elements such as arsenic, cadmium, chromium, iron, lead, manganese, and zinc (Parliman and others, 1980; Jacobson, 1982, 1984; Yee and Souza, 1984; and S.L. Lund, Idaho Department of Health and Welfare, oral commun., 1986). Cyanide, mercury, and arsenic also are potential contaminants in several mountain valleys, principally in central Idaho.

Locations of municipal landfill sites are shown in figure $3 C$. Landfills receive domestic, agricultural, and industrial-waste materials including aquaculture sludge, municipal waste-treatment sludge, liquid and solid septic-tank wastes, and probably small quantities of hazardous wastes. Effects of landfills on ground-water quality currently (1986) are not being monitored routinely.

\section{Potential for WATER-Quality Changes}

Degradation of water quality from migration of petroleum and hazardous wastes from numerous disposal, storage, transfer, or spillage sites is a primary concern in urban areas. In the basalt aquifer of the eastern Snake River Plain, water quality may also be affected by agricultural practices and the widespread use of drain wells, land spreading of wastes, and disposal of low-level radioactive and chemical waste at the Idaho National Engineering Laboratory. The potential exists for water quality to be affected by increased concentrations of trace metals in ground water in the mining district in northern Idaho and phosphate-ore and fertilizer processing areas in southeastern Idaho. Areas with the most intensive land-use activities and the greatest potential for land- or wateruse effects on ground-water quality are in both the eastern and the western Snake River Plain and in the northern Idaho valleys.

Background water-quality data are sparse in Idaho, particularly in recharge areas. Few analyses are available on organic compounds, such as pesticides and toxic wastes from household and industrial chemicals. The potential effectiveness of some ground-water management activities may be affected by lack of longterm, comprehensive monitoring programs.

\section{GROUND-WATER QUALITY MANAGEMENT}

Management of ground-water resources and protection of these resources from contamination are the responsibilities of the Idaho Department of Water Resources (IDWR), Department of Lands; Department of Agriculture; and Department of Health and Welfare, Division of Environment (Bureau of Water Quality and Bureau of Hazardous Materials). Limited protection of ground-water resources presently (1986) is provided through statewide regulations for various activities.

Regulatory and administrative authority for ground-water protection is provided by State statutes and Federal regulations. The IDWR has authority to assess ground-water resources, including aquifer mapping and data collection of nonthermal and thermal resources, and federally delegated responsibility to regulate injection wells. The Idaho Department of Lands is responsible for protection of ground water from oil and gas drilling operations. This agency also directs State programs in surface mining, dredge mining, and rural forestry-activities that can result in ground-water contamination. The Idaho Department of Agriculture has been delegated responsibility for the Federal Pesticides Enforcement Program.

Most State statutes and federally delegated authority are the responsibility of the Idaho Department of Health and Welfare, including regulation of General Water Pollution Control and Public Water System programs. The Division of Environment, Water Quality Bureau, of the Idaho Department of Health and Welfare is the lead agency in managing the quality of Idaho's ground water. In 1983, the Water Quality Bureau published the State's first comprehensive Groundwater Quality Management Plan (Martin, 1983), which outlines a coordinated approach to ground-water quality management among several State agencies. Since 1983, a management strategy has been developed for the basalt aquifer of the eastern Snake River Plain (Idaho Department of Health and Welfare, 1986a). Regulations or guidelines have been revised or established for 16 potential contaminant sources, and 10 original program elements are ongoing or have been completed, including hazardouswaste regulations and the Contamination Log.

A second edition of the Groundwater Quality Management Plan was published in 1985 (Idaho Department of Health and Welfare, 1985c) to update work on ground-water-quality programs, assess the current status of the plan, and propose additional direction for Idaho's ground-water-quality management. Current groundwater management priorities include establishment of a management strategy for valley-fill aquifers in northern Idaho; ground-water policy and water-quality standards (selected inorganic and organic compounds); a dedicated statewide monitoring program; guidelines for cyanide leachates and feedlots; and regulations for underground storage tanks, land application of wastewater, and pesticide container and equipment rinse-water handling.

Ground-water-quality monitoring data are obtained primarily through the State's drinking-water program. This program consists of about 2,600 public-supply systems that are analyzed periodically for selected water-quality characteristics. From 1975 through 1982, the U.S. Geological Survey, in cooperation with the IDWR, established reconnaissance ground-water-quality data bases for areas where land and water-resource development was expected to increase, but the program was discontinued after studies in seven areas were completed. The U.S. Geological Survey, in cooperation with the IDWR, published a ground-water-quality monitoring network plan in 1979 (Whitehead and Parliman, 1979). Also, a project proposal for statewide ground-water-quality monitoring was developed by the U.S. Geological Survey and the Idaho Department of Health and Welfare in 1985, but the project has not been implemented. Current monitoring activities consist of water-level measurements and occasional ground-water analyses for site or areal studies by numerous local, State, and Federal agencies. 


\section{SELECTED REFERENCES}

Burr, Gwen, 1986, Idaho water quality status report: Boise, Idaho Department of Health and Welfare, $106 \mathrm{p}$.

Idaho Department of Health and Welfare, 1985a, Snake Plain aquifer technical report: Boise, Idaho Department of Health and Welfare, $117 \mathrm{p}$.

1985b, Idaho environmental quality profile 1985: Boise, Idaho Department of Health and Welfare, $61 \mathrm{p}$.

1985c, Groundwater quality management plan for Idaho: Boise, Idaho Department of Health and Welfare, 23 p.

1986a, Snake Plain aquifer management strategy: Boise, Idaho Department of Health and Welfare, $26 \mathrm{p}$.

1986b, 1985 Summary of Idaho's Contamination Log: Boise, Idaho Department of Health and Welfare, 5 p.

Jacobson, N.D., 1982, Ground-water conditions in the eastern part of Michaud Flats, Fort Hall Indian Reservation, Idaho: U.S. Geological Survey Open-File Report 82-570, 35 p.

1984, Hydrogeology of eastern Michaud Flats, Fort Hall Indian Reservation, Idaho: U.S. Geological Survey Water-Resources Investigations Report 84-4201, 31 p.

Jones, F.O., and Lustig, K.W., 1977, Ground-water quality monitoring, Rathdrum Prairie aquifer: Coeur d'Alene, Idaho, Idaho Conference of Health Districts, Panhandle Health District No. 1., 94 p.

Leenheer, J.A., and Bagby, J.C., 1982, Organic solutes in ground water at the Idaho National Engineering Laboratory: U.S. Geological Survey Water-Resources Investigations 82-15, $39 \mathrm{p}$.

Lewis, B.D., and Jensen, R.G., 1984, Hydrologic conditions at the Idaho National Engineering Laboratory, Idaho, 1979-1981 update: U.S. Geological Survey Open-File Report 84-230, 65 p.

Martin, S.B., 1983, Groundwater quality management plan for Idaho: Boise, Idaho Department of Health and Welfare, $24 \mathrm{p}$.

Parliman, D.J., 1983, Ground-water quality in the western Snake River basin, Swan Falls to Glenns Ferry, Idaho: U.S. Geological Survey Water-Resources Investigations Report 83-4062, 85 p.

1986a, Compilation of well and ground-water quality data, Groveland-Collins and surrounding areas near Blackfoot, Bingham County, Idaho: U.S. Geological Survey Open-File Report 86-127, $113 \mathrm{p}$.

1986b, Quality of ground water in the Payette River basin, Idaho: U.S. Geological Survey Water-Resources Investigations Report 86-4013, 85 p.

Parliman, D.J., and Brower, Cheryl, 1985, Directory of ground-water information in Idaho: Boise, Idaho Department of Health and Welfare, $31 \mathrm{p}$.
Parliman, D.J., Seitz, H.R., and Jones, M.L., 1980, Ground-water quality in north Idaho: U.S. Geological Survey Water-Resources Investigations Open-File Report 80-596, 34 p.

Robertson, J.B., Schoen, Robert, and Barraclough, J.T., 1974, The influence of liquid waste disposal on the geochemistry of water at the National Reactor Testing Station, Idaho, 1951-70: U.S. Geological Survey Open-File Report IDO-22053, 231 p.

Sun, R.J., ed., 1986, Regional Aquifer-System Analysis program of the U.S. Geological Survey, summary of projects, 1978-84: U.S. Geological Survey Circular 1002, 246 p.

U.S. Department of Defense, 1986, Information paper-status of the Department of Defense Installation Restoration Program: Washington,D.C., Office of the Assistant Secretary of Defense (Acquisition and Logistics), $35 \mathrm{p}$.

U.S. Environmental Protection Agency, 1986a, Maximum contaminant levels (subpart B of Part 141, National interim primary drinking-water regulations): U.S. Code of Federal Regulations, Title 40, parts 100-149, revised July 1, 1986, p. 524-528.

1986b, Secondary maximum contaminant levels (section 143.3 of part 143, National secondary drinking-water regulations): U.S. Code of Federal Regulations, Title 40, parts 100 to 149 , revised July 1 , 1986 , p. $587-590$.

1986c, Amendment to National Oil and Hazardous Substances Contingency Plan, national priorities list, final rule and proposed rules: Federal Register, v. 51, no. 111, p. 21053-21112.

U.S. Geological Survey, 1985, National water summary 1984-Hydrologic events, selected water-quality trends, and ground-water resources: U.S. Geological Survey Water-Supply Paper 2275, 467 p.

Westrick, J.J., Mellow, J.W., and Thomas, R.F., 1984, The ground water supply survey: Journal of the American Water Works Association, v. 76 , p. $52-59$.

Whitehead, R.L., and Parliman, D.J., 1979, A proposed ground-waterquality monitoring network for Idaho: U.S. Geological Survey WaterResources Investigations Open-File Report 79-1477, 67 p.

Wood, W.W., and Low, W.H., 1987, Solute geochemistry of the Snake River Plain regional aquifer system, Idaho and eastern Oregon: U.S. Geological Survey Open-File Report 86-247, 147 p.

Yee, J.J.S., and Souza, W.R., 1984, Quality of ground water in Idaho: U.S. Geological Survey Open-File Report 83-50, 78 p.

Young, H.W., and Mitchell, J.C., 1973, Geothermal investigations in Idaho, part 1, Geochemistry and geologic setting of selected thermal waters: Idaho Department of Water Administration, Water Information Bulletin No. 30,43 p.

Prepared by D.J. Parliman

FOR ADDITIONAL INFORMATION: Idaho Office Chief, U.S. Geological Survey, Water Resources Division, 230 Collins Road, Boise, Idaho 83702 


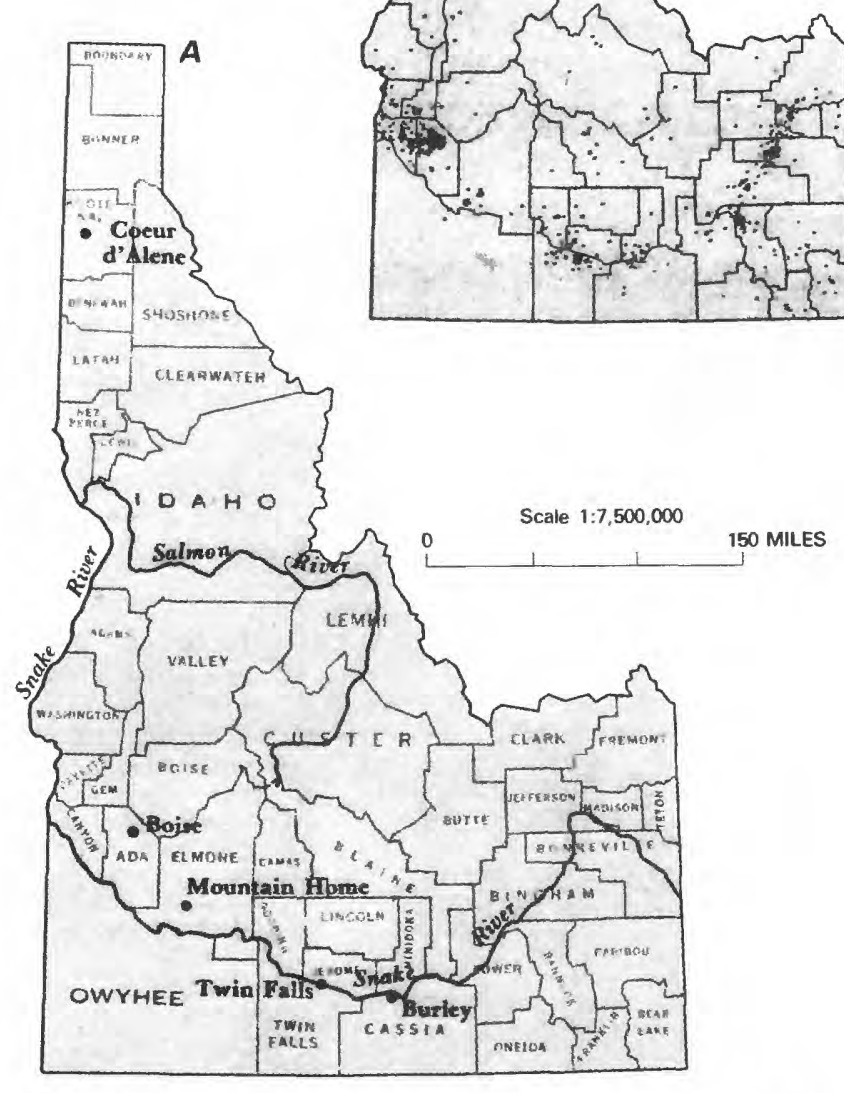

Figure 1. Selected geographic features and 1985 population distribution in Idaho. $A$, Counties, selected cities, and major drainages. $B$. Population distribution, 1985; each dot on the map represents 1,000 people. (Source: B. Data from U.S. Bureau of the Census 1980 decennial census files, adjusted to the 1985 U.S. Bureau of the Census data for county populations.) 


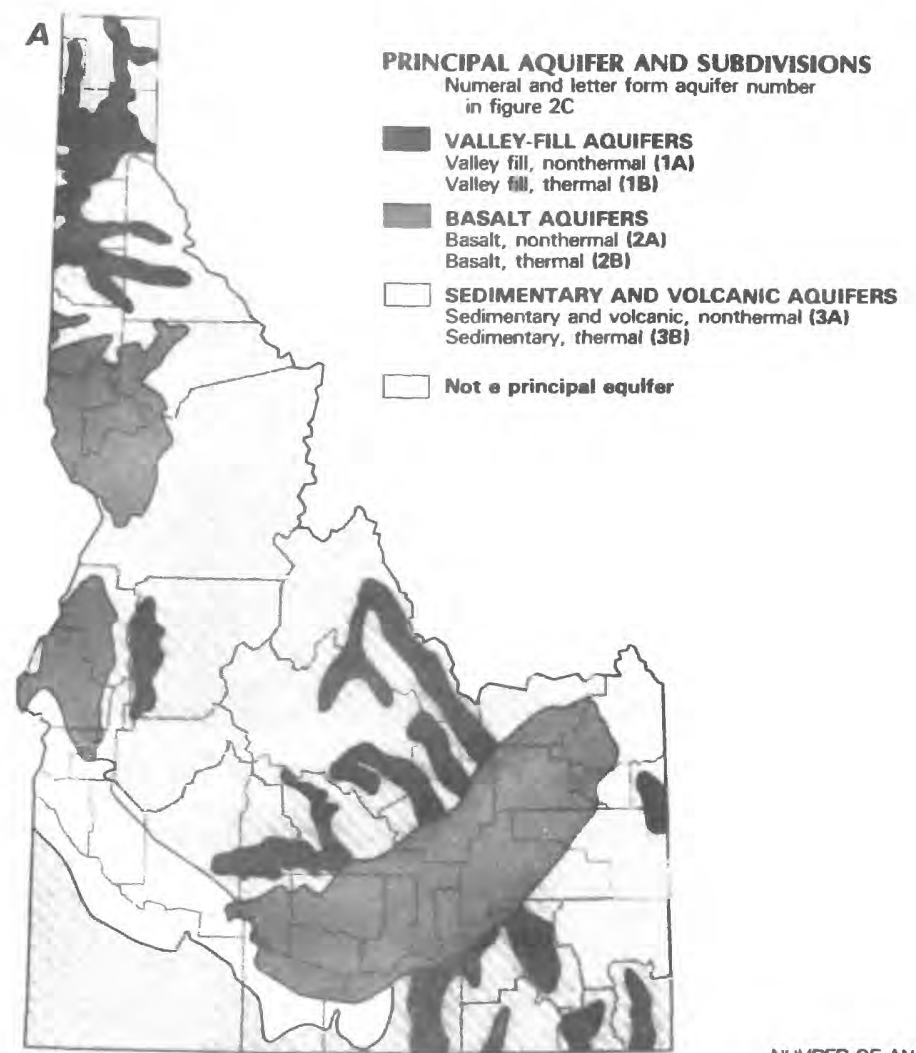
DIVISIONS

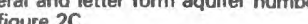

VALLEY-FILL AQUIFERS

BASAT AQUIFERS

SEDIMENTARY AND VOLCANIC AQUIFERS Sedimentary and volcanic, nonthermal (3A)

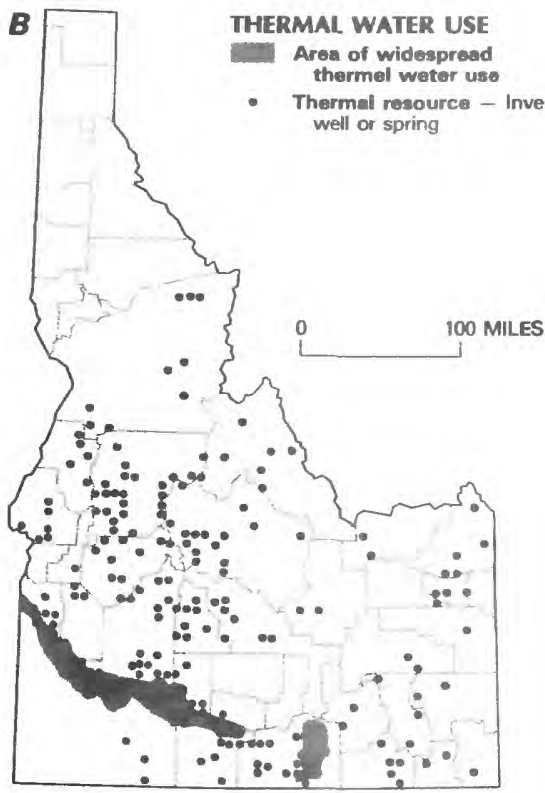

NUMBER OF ANAIYSES

C WATER-QUALITY DATA

Percentlle - Percentage of analyses equal to or less than indicated values

$$
\begin{aligned}
& 90 \mathrm{th} \\
& -75 \mathrm{th} \\
& -50 \mathrm{th} \\
& -25 \mathrm{th} \\
& -10 \mathrm{th}
\end{aligned}
$$

National drinklng-water wtandurds

- Maximurn permissible contominant level (primary)

- - Maximum recommended contaminam level (secondary)

- - Maximum recommended range $\mathrm{pH}$ (secondary)

Reporting Itmits

Minimum reporting level with analytical method

MUMBER OF ANAUYSES

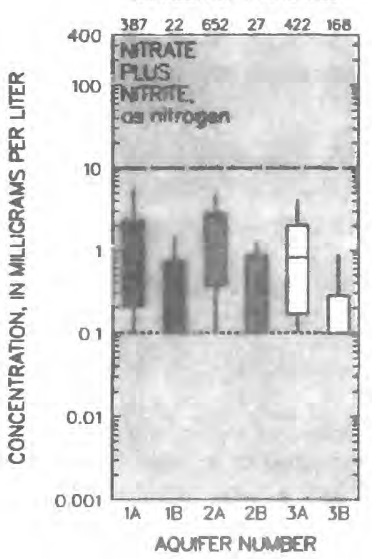

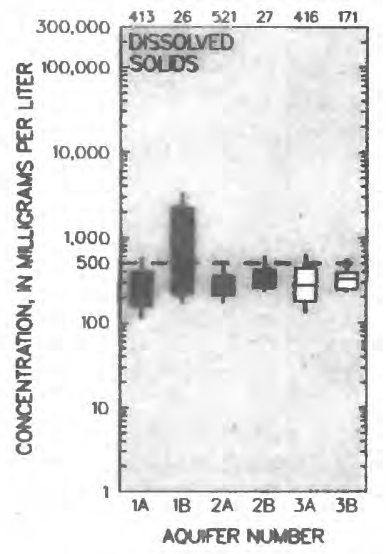

MUMEER OF ANAUSES

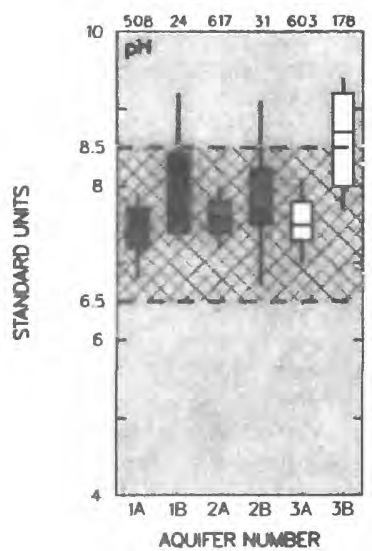

NUMBER OF ANALYSES

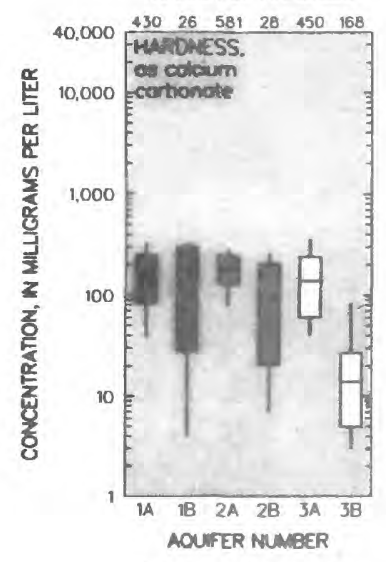

NUMBER OF ANALISES

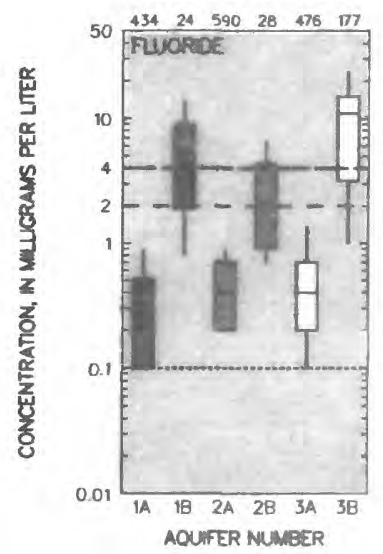

Figure 2. Principal aquifers and related water-quality data in Idaho. A, Principal squifers. $\boldsymbol{B}$, Thermal water-use areas. $\boldsymbol{C}$. Selected water-quality constituents and properties, as of 1970-86. (Sources: A, U.S. Geological Survey, 1985; Burr, 1986. B, Yee and Souza, 1984. C, Analyses compiled from U.S. Geological Survey files; national drinking-water standards from U.S. Environmental Protection Agency, 1986a,b.) 


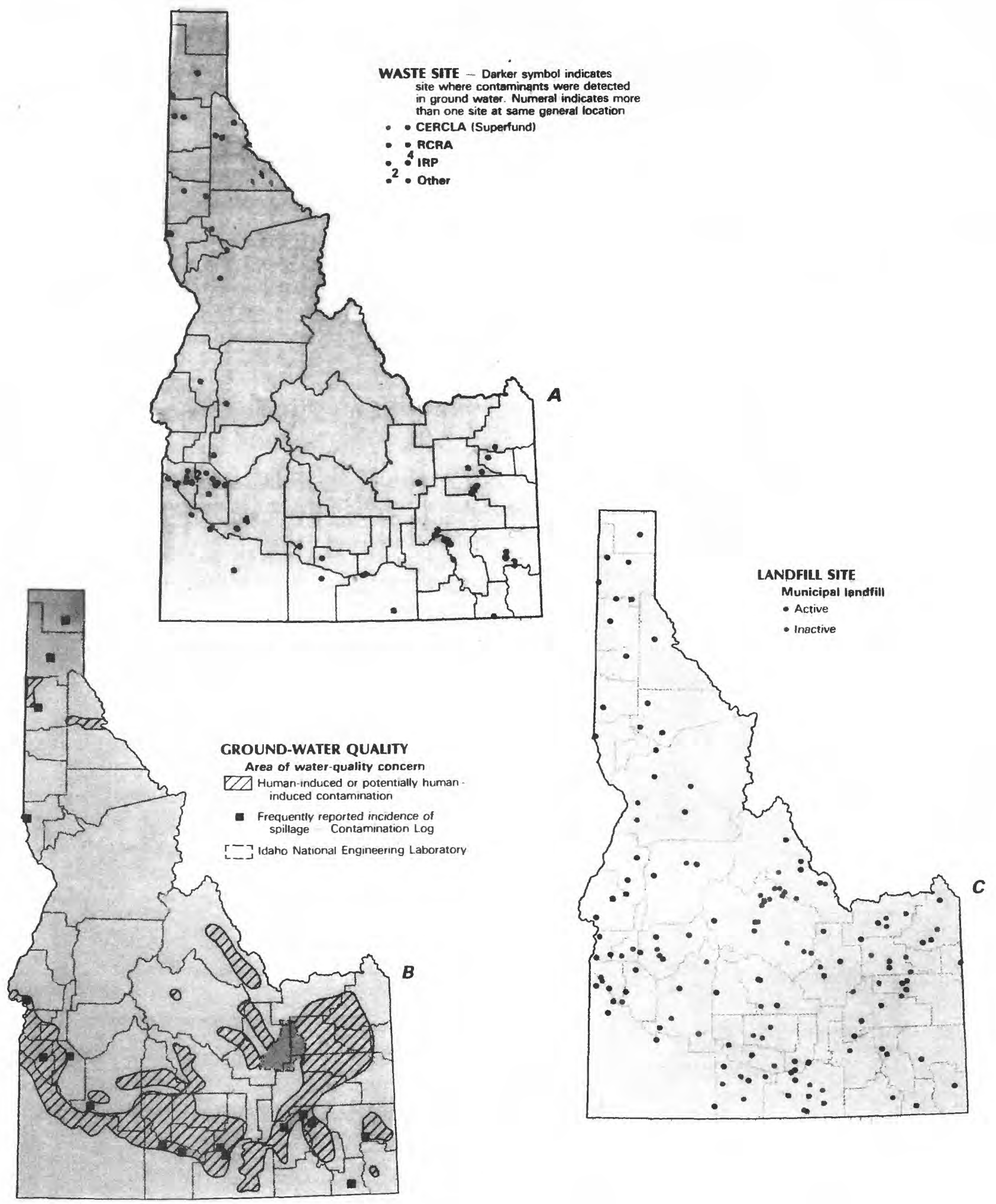

Figure 3. Selected waste sites and ground-water-quality information in Idaho. A, Comprehensive Environmental Response, Compensation, and Liability Act (CERCLA) sites, as of July 1986; Resource Conservation and Recovery Act (RCRA) sites, as of July 1986; Department of Defense Installation Restoration Program (IRP) sites, as of September 1985; and other selected waste sites, as of July 1986. B. Areas of human-induced or potential contamination and location of frequently reported incidences of spillage, as of July 1986. C. Municipal landfills, as of July 1986. ISources: $A$, Cathy Ardakan, U.S. Environmental Protection Agency, written commun., 1986; Deborah Flood, U.S. Environmental Protection Agency, written commun., 1986; J.E. Jankowski, Idaho Department of Health and Welfare, written commun., 1986; S.L. Lund, Idaho Department of Health and Welfare, oral commun., 1986; U.S. Department of Defense, 1986. B. Yee and Souza, 1984; W.G. Graham, Idaho Department of Water Resources, written commun., 1988; Idaho Department of Health and Welfare, 1986b. C, J.E. Jankowski, Idaho Department of Health and Welfare, written commun., 1986.) 